\title{
Chico Mendes Lives: Amazon women in defense of life
}

\author{
Angela Mendes \\ Claudelice Santos \\ Edel Moraes \\ Sônia Bone Guajajara
}

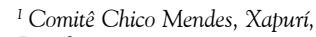
Brazil

"I Universidade Federal do Sul e Sudeste do Pará (UNIFESSPA) e Instituto Zé Claudio e Maria, Marabá, Brazil

"II Memorial Chico Mendes e CAUIM/UNB, CurralinhoArquipélago do Marajó, Brazil

${ }^{\text {IV }}$ Articulação dos Povos Indígenas do Brasil, Brasília, Brazil

\begin{abstract}
This narrative is the result of the round of talks "Chico Mendes Vive", held during the III Latin American Congress of Political Ecology. It is a living experience of four Amazonian women, Angela Mendes, Claudelice Santos, Edel Moraes and Sônia Guajajara, whose speeches emerge from the experience of indigenous, black, cabocla, agro-extractivist women, who make of their lives a struggle in defense of Mother Earth and of the "common good", which aggregates, welcomes and feeds all the other forms of being in the universe. This narrative expresses the continuity of the re-existence of native and indigenous peoples, the reconnection of the peoples of the forest, water and countryside, through the legacy left by Chico Mendes, a son of the Amazon, who was assassinated for defending and fighting for life.
\end{abstract}

Keywords: Chico Mendes, Amazon, resistance, violence, common

São Paulo. Vol. 24, 2021

Narratives and Reflections: Decolonial Insurgencies and Emancipatory Horizons

DOI: http://dx.doi.org/10.1590/1809-4422asoc20210154vu2021L5NR 
This report is the result of the roundtable "Chico Mendes Lives", held on 22 March 2019, during the III Latin American Congress of Political Ecology. The following is an escrevivência [the writing of life, and that written by life] of four Amazon women, whose talks emerged from the experience of Indigenous, Black, cabocla, agroextractivist women, who have dedicated their lives to struggle in defense of Mother Earth, the "common good" that aggregates, shelters and nourishes all other forms of being in the universe. This register expresses more than thoughts, they are true stories of women from the Amazon. What unites us is the pain of loss of loved ones; anguish and fear transformed into the courage to raise our bodies, donate and have our voices be heard; the clamor in defense of the entire environment (of which we are only a small particle); the strength of walking with hope, of sharing dreams and utopias, without ever being silent or failing to denounce the violations against traditional peoples and communities of Brazil. It is the continuity of re-existence as original and Indigenous peoples, the reconnection of the peoples of the forest, of the waters and of the fields through the legacy left by Chico Mendes, a son of the Amazon, who was assassinated for defending and fighting for life.

We denounce the threats and deaths, we defend our territories, we announce our conquests, we socialize our knowledge, we share dreams and utopias. We are happy to be together in a round table. This leads us to think and believe that we are not alone in this confrontation that life imposes on us and gives us hope that we can reach many others so they can join us. Good reading and reflection for everyone.

\section{The pain of denunciation in the talks and the hope in the acts in defense of the common good}

In early 2019, Ricardo Salles was named Minister of the Environment in Brazil. In an interview, upon being questioned about Chico Mendes, he responded: "Why is Chico Mendes important today?" Chico Mendes, a son of the Amazon, known worldwide, was assassinated for fighting for and defending the forest and rubber tappers In the state of Acre, Brazil. His legacy goes beyond the rubber plantations of Acre, he placed a seed that has bloomed in various biomes of Brazil.

One of his most famous sayings is: "At first I thought I was fighting to save the rubber trees, then I thought that I was fighting to save the Amazon, now I know that I am fighting for everyone on the planet". With this statement, I, Edel Moraes, when I was vice-president of the National Council of Extractivist Populations, invited Sônia Guajajara to a roundtable, the first Indigenous woman to run for the vice presidency of Brazil in 2018, Angela Mendes, the Women's Secretary of the National Council of Extractivist Populations (formerly the National Council of Rubber Tappers) and Claudelice Santos, who is the sister of José Cláudio and Maria do Espirito Santos, who were also killed for defending a collective territory. 
To begin the dialog, we will do a collective reading of the words of a song by Vital Farias, "A Saga da Amazônia" [The Saga of the Amazon]:

Once upon a time there was a beautiful forest in the Amazon (...)

Caipora came from beyond to weaken the forest

And brought the iron dragon to eat lots of wood And brought 'estilo gigante', to do away with the capoeira

Soon they made a project without anyone seeing

For the dragon to eat the wood and tear down the whole forest

If my friend the forest, had feet to walk

I am sure my friend would not have stayed there with the danger

What you cut in seconds, takes time to grow again

And the bunch of fruit for us to eat? (...)

Then, we asked: How can we consider that Chico Mendes is still alive? What is his legacy to the Brazilian people? We will now hear from Angela Mendes, who has inherited not just her father's name, but his struggle, which makes life re-existence:

Last year (2018), in December, we brought together 500 people in Xapuri, including men and women comrades from forest and marine extractivist reserves of the Amazon and other Brazilian biomes, admirers and supporters of the struggle of Chico Mendes, people from various places on this planet where Chico achieved important partnerships to strengthen the struggle of traditional extractivist peoples. The act is part of the annual program of the Chico Mendes Week, coordinated by the Chico Mendes Committee with the theme: "Chico Mendes, a memory to honor, a legacy to defend".

But what legacy are we speaking of? We are speaking of education and territory, conquests that were fundamental to the consolidation of this revolutionary model of agrarian reform in the Amazon. The "Rubber Tappers Project", which adopted a methodology from Paulo Freire, was created in 1981 by Chico Mendes and Mary Allegretti to prepare instructors to teach rubber tappers to read and write, people who until then were kept in semi-slavery by their rubber plantation bosses, who were taking advantage of the fact that the rubber tappers did not know numbers, always left them with gigantic debts (the owners of the rubber plantations were also suppliers of the food and provisions for their shacks), so that they worked day and night to produce rubber to pay a debt that had no end. The first school was built in the Seringal Nazaré and was a small wattle and daub shack, very simple and rustic. The area of action of the project was the region of Xapuri and Epitaciolandia. In 2007, when it was presented to the public educational system it already had 100 schools with modern structures and with nearly 2,000 
students who had learned to read and write, some had already graduated from the Universidade Federal do Acre (UFAC). Some of them returned to their community to contribute and apply their knowledge, mainly in the field of education as rural administrators and teachers. This project was recognized and received various awards, including from UNICEF-Brazil. This was the legacy of Chico Mendes in education.

The conquest of the extractivist reserves involved a long and difficult process of mobilization, union organization and political articulations, led by Chico Mendes, and which led to the First National Encounter of Rubber Tappers, in 1985, in Brasilia. The results of the entire effort to mobilize some 150 men and women rubber tappers from Acre, Amazonas, Rondônia, Pará and Amapá was the definition of the extractivist reserves as the ideal model for ecological collective agrarian reform for the The Amazon basin, considering its particularities and the creation of the National Council of Rubber Tappers (CNS), now the National Council of Extractivist Populations. The first extractivist reserves (Resex) were created in 1990. I always say that my father conceived two daughters but did not get to see them grow.

With the same objective of sustainable use and with Resex as a model, other territories were being created such as Marine Extractivist reserves, Reserves for Sustainable Development and Projects of Differentiated Settlements, which, combined, contribute to the protection of more than 60 million hectares of forest and mangroves and thousands of families. This is not just any legacy, it is the legacy of life. This force that moved these peoples back then is the strength that drives us to continue the struggle, because until today, Amazon is only valued for marketable economic assets such as wood, cattle, soybeans, mining, energy, without considering cultural, historic, and ancestral aspects of the traditional knowledge. These are priceless.

But the struggle is for all of us, for this reason we are here, because we cannot resist alone, we must join in a large resistance front for the Amazon, including the various movements and segments that continue to be threatened as are we, including, particularly, the university, and this is what we are doing here now, calling for the struggle in defense of the forests and waters.

\section{We will now hear from, Claudelice Santos:}

The bodies disappear, but the history remains, and this is why we are here to tell it. This is why you are listening, to continue to tell this story, to not let this history die. My name is Claudelice Santos and I lived in an extractivist settlement called Praia Alta Piranheira in Nova Ipixuna, Para. And in 2011 I had to leave my settlement because they killed my brother and my sister-in-law, in an ambush, on a bridge, so they could not get away. They had no chance for defense, his ear was cut. They were taken from the road, dragged to the edge of the forest where they finished executing both of them.

Why did they kill Zé Cláudio and Maria? Because they are also the legacy of Chico, because when they lived in the middle of the forest, with another perspective and nearly without hope, it was from this legacy, it was from the struggle of Chico Mendes that they gained their strength to enter the environmental movement and struggle for the legalization of land, to fight so that the settlement would be created in another way: with a perspective of conservation and not like in Southern and Southeast Pará, which is divided into lots. [It is] another way of looking at the Earth, another way of seeing people, considering each one's way of life, considering a means of production that involves sustainable use of the earth.

Over the years, until they were assassinated, until they were taken from us, they fought so that the entire settlement would finally be free and that the people who needed the land, 
forest, and a place to work, had them. Then they began to denounce the extraction of wood, because when the region began to be legalized, the farmers who were the "owners" began to allow lumberers to remove wood, because they knew that there was a group of resistance who would not leave that public land, in the public domain, in the hands of the few while there were many people who needed it.

They saw that when there is someone making a denunciation, she is shouting for help in a situation. The forest has no mouth to shout with, but it has us to protect it. So it is up to us to do this and this is what we did. The cry that came from the ghettos, the cry that came from the terreiros.

Chico Mendes lives when each one of us speaks of him, of his struggle, to keep his memory alive, [and that of] Zé Claudio, Maria and Marielle as well. I know that most of you also felt the struggle, the pain that we went through, when we speak, when we relive the pain, every day, each time we remember our martyrs. And not one minute of silence for the martyrs, but a life of struggle.

\section{Our greatest wealth is Mother Earth}

\section{Invited to continue, Sônia Guajajara began by denouncing:}

They don't only kill, just when they physically kill, but they also kill when they take away our right to exercise our ways of life. We are tired of seeing our people abused, to see our people die, to see our kin being sacrificed, excluded, decimated every day. So this is why we are here, this is why we are always traveling.

The Brazilian state was the greatest instrument of theft of Indigenous lands. This struggle is very violent, it is not an individual struggle, it is not a struggle of individuals, it is always a collective struggle in defense of the common good. The state of Bahia in Brazil has this historic meaning for us. This is where the first process of extermination began and it was not by chance, it was planned extermination: first by the Europeans and (...) by the Brazilian state. Then this history of economic growth, of progress, of development, the origin of this, the matrix of this growth always took place based on extermination, in genocide and in the blood of our peoples. Who were the first people attacked? The Indigenous peoples and the peoples of African origin. Today we see this reflected in the Amazon, we are living through an entire violent process (...).

The Indigenous peoples were almost wiped out. For a long time we were denied our identity. Today we are in a process of seeking out our origins of self-determination, of selfknowledge. They silenced us, but now the people rise up to assume their roots. They tried to take our identity, because when they take the territory, you also take the identity. It's when we can't exercise our way of life, and we are no longer who we are. The Brazilian state stole Indigenous lands to give them to farmers. When we struggle to take them back, we are called invaders. And today, in Brazil, the agriculture lobby often says this. Thirteen percent of Brazilian territory is Indigenous territory, but if you look at it another way, you see that $1 \%$ of the large landowners hold $46 \%$ of the private properties. How come this number is not stated as well? When we make this struggle, it is a collective struggle, it's for the entire world. It's precisely these lands that we defend, that we protect, that are guaranteeing life on the planet. So we need not only to think about the importance of Indigenous lands, which [are] the conservation units, which the traditional extractivist populations are guaranteeing, but we have to begin to also think about these issues of concepts, what is the university doing to change this understanding, this comprehension of what is important and essential to guarantee life. 
Then there is the constant intention from the outside to say that [we]are backwards. We are backwards because we are in the fields, because we are in the pasture, because we are in the forest. Civilization did not reach there yet, that is how they treat us. The idea of growth, of development, of progress in the city, of those who destroy rivers, of those who put cement on top of everything, who cut down trees, this that is called progress. This is completely inverted. (...) We have to invert this and begin to have people think, and understand, to do away with this duality that there is between what is backwards and what is growth.

So the people who also say that they support [us], that they are concerned, who say that they are on our side, can we all begin to understand and put this in practice? We will never change, we won't because we only keep talking, and we don't have time for talking, thinking. We have to act, together.

Our alliance of the peoples of the forest with the traditional extractivist communities (...) was never broken because we have the same understanding about the use of land. And today, in Brazil, the biggest conflict is this dispute over land, because it's everyone, the economic and political forces, they want to put their hands on these territories, they want to relax the environmental laws to be able to build more projects, change the law (...) and facilitate exploitation (...).

So we also have to think today, mainly in an environment that has so many different people from various segments, (...) with this wonderful Congress that has connections with various countries, (...) these things that bring us together. (...) And we speak here, talking about all this that is happening, but we do not want people to look at us and have pity for us. No, not at all. We want people to recognize us for our strength, for what we do to protect and defend the life of so many people. We must think of a political project for the country. (...) It's no use to stay online saying: "I don't want this".

We must come together and think of a political bem viver project, what is the project that we want, what do we think about our life, what do we think of as a development project. (...) We don't want this same kind of "development". What we want is a bem viver project based on the involvement of people, with a concern for care, protection, environmental preservation. It's mother nature, which is Mother Earth, who promises us life, that is at stake (...) So when we think that this is all heading towards chaos, what can we do to break away from this model? What can we do so that there is greater understanding in society so that the life that we have in the city connects with the life that we have there in the fields? Why is it so difficult for us, why is our political struggle to guarantee the life of the whole world costing the life of our people? It already took the life of Angela's father, it already took the life of Claudelice's brother and sisterin-law, and it's taking the lives of many people.

We have lots of questions, we have lots of blood.

\section{Chico Mendes Lives}

The dialog took place narrating the acts and facts of the history that connects Indigenous peoples and traditional communities of Brazil. This history began with the usurpation of the territories of the original Brazilian populations - the Indigenous allied to the genocide of peoples, including peoples who were forcibly taken to Brazil and enslaved. It continues with the process of miscegenation of the people, marked by violence, forming the traditional communities, intentionally made invisible in Brazil, but who insist on the right to live with dignity and respect for their ways of life.

What we have in common is the struggle and defense of Mother Earth, the defense 
of collective territories, which are our greatest common good. These are territorial spaces like the Indigenous Lands, the Conservation Units or the agro-extractivist settlements. The histories interlinked and reconnected in the three talks indicate to us that the historic process of colonization and implantation of "development" left deep marks that are still visible. They also show that the main dispute is related to the domination of the earth for exploitation, whether of minerals or lumber, or to implant mega-infrastructure projects, like hydroelectric dams and railroads. In this way, we live with the threat and the continuity of genocides and ethnocides, as mentioned by Sônia Guajajara.

Chico Mendes, a defender of the Amazon and of the rubber tappers, saw in the Indigenous form of territorial organization an opportunity to construct a proposal for land regulation, in a format of collective territories. This led to the extractivist reserves, which are one of the main legacies left by Chico. Many traditional communities beyond the Amazon benefitted from this conquest, reaffirming a way of life in the territories that is similar to that of the Indigenous peoples. In this way, it can be said that the institution of the extractivist reserves and the initiatives that come from them constitute Chico Mendes' main legacy, and have been defended, expanded and consolidated by way of more than 600 collective territories and by hundreds of associations and cooperatives, large and small, that have the responsibility to manage this heritage, together with government agencies: the Chico Mendes Institute for the Conservation of Biodiversity (ICMBio) at the federal level, the secretariats of the environment at state level, and Incra, for the rural settlements. The idea of the conservation units, the extractivist reserves, has been connected with the alliance of the peoples of the forest since the 1980s.

All of the talks also denounced the threats and violations of rights to life and the advance of predatory exploitation. Therefore, our proposals are based on the urgency of the connections of the peoples of the forest, the fields, the water areas and the city, and that this connection, as Sonia warned, goes beyond social media, to a collective thinking about which project we want for the world. We propose a project with the involvement of people and the entire environment, with the vision that we are part of it, and only with the environment alive and healthy can we save our lives. The pain, the struggle that joins us in roundtables or panel discussions, in various spaces also brings us strength and has courage and determination grow in us, so we can believe that another world is possible.

Angela Mendes reinforces the initial process of Chico Mendes based on education for liberty. This is in synergy with what Sonia said, when she affirmed that the university must be a partner and we must rethink the concepts discussed in the university, warning that this is a collective struggle and that it involves the fields, the city, and the peripheries. Moreover, she reaffirmed that the violence, the threats, and the deaths also take place when territory is taken or denied and how this also leads to denial of identities of indigenous and quilombola peoples or traditional communities.

Therefore, Chico Mendes lives in each act and action that we take to defend the earth, the territories and education for the liberty of a people.

\section{Acknowledgements}

This roundtable was supported by Capes, CNPQ and SINASEFE-IFBA. The editors 
and editor would like to thank the student Júlia Mota de Brito for transcribing this roundtable. The translation of the document was supported by a research project financed by the British Academy (SDP2 $\backslash 100278$ ) "Sustainable Development' and atmospheres of violence: experiences of environmental defenders" and by the University of Sussex/ Research England/Global Challenges Research Fund (IDCF1G262626-08), as part of the "Other Sky": mapping of violence against Indigenous Peoples in Brazil" a collaboration between the Universidade Federal da Bahia (UFBA), Universidade Federal do Recôncavo da Bahia (UFRB), professor Felipe Milanez Pereira from the Institute of Humanities. Arts and Sciences Milton Santos (IHAC) - Universidade Estadual da Bahia (UNEB), and the Universidade de Sussex and executed by Fapex. 


\section{Angela Mendes}

$\checkmark$ angelamfmendes@gmail.com

ORCiD: https://orcid.org/0000-0001-8806-8293
Submitted on: 02/09/2021

Accepted on: 06/09/2021 2021;24e:0154

\section{Claudelice Santos}

$\checkmark$ claudelicesantos2@gmail.com

ORCiD: https://orcid.org/0000-0003-0452-7654

\section{Edel Moraes}

凹edelmoraes@gmail.com

ORCiD: https://orcid.org/0000-0002-3731-6135

\section{Sônia Bone Guajajara}

$\varangle$ soniaguajajara@gmail.com

How to cite: MENDES, A.; SANTOS, C.; MORAES, E.; GUAJAJARA, S. Chico Mendes Lives: Amazon women in defense of life. Ambiente $\mathbb{\&}$ Sociedade. São Paulo, v. 24, p. 1-09, 2021. 


\title{
Chico Mendes Vive: Amazônidas em defesa da vida
}

\author{
Angela Mendes \\ Claudelice Santos \\ Edel Moraes \\ Sônia Bone Guajajara
}

São Paulo. Vol. 24, 2021

Narrativas e reflexões: Insurgências Decoloniais e Horizontes Emancipatórios
Resumo: Este relato é resultado da roda de conversa "Chico Mendes Vive”, realizada durante o III Congresso Latino-Americano de Ecologia Política. É uma escrevivência de quatro mulheres Amazônidas, Angela Mendes, Claudelice Santos, Edel Moraes e Sônia Guajajara, cujas falas emergem da experiência de indígenas, pretas, caboclas, agroextrativistas, que fazem de suas vidas uma luta em defesa da Mãe Terra e do "bem comum", que agrega, acolhe e alimenta todas as demais formas de ser e estar no universo. Essa narrativa expressa a continuidade da re-existência de povos originários e indígenas, a reconexão dos povos da floresta, das águas e do campo, através do legado deixado por Chico Mendes, um filho da Amazônia, que foi assassinado por defender e lutar pela vida.

Palavras-chave: Chico Mendes, Amazônia, resistência, violência, comum.

Como citar: MENDES, A.; SANTOS, C.; MORAES, E.; GUAJAJARA, S. Chico Mendes Vive: Amazônidas em defesa da vida Ambiente \& Sociedade. São Paulo, v. 24, p. 1-09, 2021. 


\title{
Chico Mendes vive: Mujeres amazónicas en defensa de la vida
}

\author{
Angela Mendes \\ Claudelice Santos \\ Edel Moraes \\ Sônia Bone Guajajara
}

São Paulo. Vol. 24, 2021

Narrativas y reflexiones: Insurgencias Decoloniales y Horizontes Emancipatórios
Resumen: Esta narración es el resultado de la ronda de charlas "Chico Mendes Vive”, celebrada durante el III Congreso Latinoamericano de Ecología Política. Es una experiencia viva de cuatro mujeres amazónicas, Angela Mendes, Claudelice Santos, Edel Moraes y Sônia Guajajara, cuyos discursos surgen de la experiencia de las mujeres indígenas, negras, caboclo, agroextractivistas, que hacen de su vida una lucha en defensa de la Madre Tierra y del "bien común", que agrega, acoge y alimenta todas las demás formas de ser del universo. Esta narración expresa la continuidad de la reexistencia de los pueblos nativos e indígenas, la reconexión de los pueblos de la selva, el agua y el campo, a través del legado que dejó Chico Mendes, un hijo de la Amazonia, que fue asesinado por defender y luchar por la vida.

Palabras-clave: Chico Mendes, Amazonía, resistencia, violencia, común.

Como citar: MENDES, A.; SANTOS, C.; MORAES, E.; GUAJAJARA, S. Chico Mendes vive: Mujeres amazónicas en defensa de la vida. Ambiente \& Sociedade. São Paulo, v. 24, p. 1-09, 2021.

DOI: http://dx.doi.org/10.1590/1809-4422asoc20210154vu2021L5NR 